\title{
Community universities in the South of Brazil: prospects and challenges of a model of non-state public higher education
}

\author{
Cristina Fioreze (University of Passo Fundo) and Tristan McCowan (University College \\ London)
}

Published in Comparative Education (2018), 54 (3), 370-389

\begin{abstract}
In recent years, higher education institutions have been encouraged to engage more strongly with their local communities, and address their historically weak links with their surrounding populations. In the latter part of the $20^{\text {th }}$ century a number of community universities were established in the South of Brazil, characterised by democratic local community involvement, expansion of access in non-metropolitan regions, and close ties with local industry. This article analyses these innovative institutions in relation to the complex demands of the so-called knowledge economy and multifaceted relationships between public and private, exploring the ways in which the public good role of universities manifests itself in relation to the local. Given their hybrid nature - independent from the state but with a public good mission - these institutions can be seen to represent a new model of non-state public higher education. Implications are drawn out for the potential role of these institutions in the current policy context of Brazil, and internationally, in light of their context-specificity and the significant challenges from the highly commercialised for-profit sector.
\end{abstract}

Keywords: Higher education; Community universities; Local community involvement; Hybridism; Public good.

\section{Introduction}

The public role of the university is conventionally framed in relation to the nation state: the student body being predominantly drawn from the national population, funding coming in the form of tax collection at the national level, and the collective goods produced being seen to enhance national economic growth, and to strengthen national culture, languages and identity. In the context of the wave of countries liberated from colonial rule in the years following the Second World War, for example, many new universities were established for the end of nation-building. However, the university in fact has a longer tradition of the international, with medieval universities being characterised by significant staff and student mobility, and having in Latin a lingua franca. Stiglitz (1999) and Marginson (2007) amongst others have explored in more recent times how the knowledge production dimension of the university links it inevitably with the global; the current fever around university rankings, and quest for 'world-class university' status, also sets institutions' sights firmly at the global level. 
On the other hand, it has become by now almost superfluous to state that globalization has also brought an increasing emphasis on the local. Higher education institutions have been encouraged to develop closer links with their communities, and some have been created specifically to attend to poorly-served regions. These forces have led to a highly complex ecology of universities with diverse spatial relationships - as highlighted in Marginson and Rhoades's (2002) conception of the 'glonacal'. While all institutions may have some links with all these of three levels, there is significant diversity of emphasis, even within the same jurisdiction: in the UK, for example, University College London tags itself as 'London's Global University', while post-1992 and new universities may draw students primarily from the local area, and more established institutions may serve students from across the country and form them for the national labour market.

This article explores two sets of interlocking relationships evident in these dynamics: the first, that between the public and private in higher education, and possibilities for promoting public good; and second, the ways in which that relationship expresses itself in relation to global, national and local. The article analyses these questions through the case of the community universities in Southern Brazil, a group of innovative institutions which counter some of the dominant global trends in higher education in order to fulfil a public role in relation to the local.

The involvement of local communities in education has been a central motif of international educational work since the latter decades of the $20^{\text {th }}$ century. Motivations for involving communities have to some extent been ones of principle, in acknowledging the importance of engaging the community, and the democratic imperative of ensuring local control; but they have also been pragmatic, in achieving buy-in to ensure the effective functioning of the school, and in some cases labour and financial contributions to safeguard schools' upkeep. Decentralisation initiatives, school-based management, parent-teacher associations and a range of other initiatives have been rolled out across the world (for example, in the USA [Blank, Melaville and Shah 2003], Sub-Saharan Africa [Miller-Grandvau and Yoder 2002], and even in regions such as Latin America in which there had previously been strong central control [Gershberg and Meade 2005; Gershberg, Meade, and Anderson 2009; Vogt 2009]). In some cases, such as the Harambee schools in Kenya, communities have established and run their own schools semi-autonomously (Mwiria 1990).

However, these initiatives have for the most part been located within basic education. In part, this focus is a reflection of the general emphasis on primary education that followed the launching of the Education for All movement in 1990 and the establishment of the Millennium Development Goals. Yet it is also due to the distinctive nature of universities as institutions and their problematic interactions with society. In fact, the relationship between universities and their local communities has through history been ambiguous to say the least. Universities have frequently had their sights set on the distant horizons, with a multi-national student and staff body, but with few links to their own geographical area. Perkin $(2007,165)$ writes of 'town and gown riots' in Oxford leading to the establishment of Cambridge University. While armed skirmishes may now be rare, universities are very commonly surrounded by impoverished communities whose young people rarely enter as students, and who receive few of the benefits of the knowledge produced within. 
Nevertheless, in recent decades critiques of the university as ivory tower have amassed, with calls for an institution more closely linked to society. Multilateral organizations such as the OECD and World Bank have intensified drives for a university that is more porous to external reality, and capable of contributing to local development. In fact, there is a tradition of university engagement with local communities going back to the $19^{\text {th }}$ century land grant universities in the USA and their links with agriculture and new industries, and the emergence of extensión as a key role of the university in Latin America, following the reforms at the University of Córdoba, Argentina in 1918 (McCowan 2016a). In contemporary times, community engagement has manifested itself in different forms: through the creation of technology hubs, science and business parks linking with local industry (Wissema 2009); synergies between universities and cities, urban planning and civic development (Ransom 2017a; 2017b); and engagement in community affairs through student volunteering and service learning (Watson et al. 2011). Nevertheless, there are few examples of communities establishing their own universities from the bottom-up; most of the above examples are of universities created by national or regional authorities which aim to reach out to local communities.

This article assesses a distinctive case of a community-based initiative within higher education. The 'community universities' in the South of Brazil (in the states of Rio Grande do Sul and Santa Catarina) were developed between 1940 and 1970 as a fruit of the mobilisation of local communities in search of higher education. Community universities are non-profit private institutions, of a non-religious character, which give the notion of community a central place in their founding missions, their current objectives and their forms of governance. Their aims are associated with a commitment to the social, economic and cultural development of the communities in which they are located, which they aim to achieve through their activities of teaching, research and public service. The management of community universities is characterised by internal democracy and collegiality, with participation of local community representatives in the governing bodies of the institution. The community model of university is a hybrid one, being characterised as both public and private at the same time, while differentiating itself both from state and for-profit private models.

The article aims to present the institutional model constituting the community universities in the South of Brazil. It aims to assess the innovative nature of this model - characterised by the organic link between university and community - as well as discuss the challenges faced by it in the contemporary policy landscape, and its prospects for addressing current tensions in higher education, both within Brazil and beyond. The article reports on a qualitative research study carried out with the community universities, involving documentary research, composed by institutional documentation (strategic documents and institutional statutes) and national legislation relating to Brazilian higher education. The study also draws on interviews with representatives of community universities: a total of 12 semi-structured interviews were carried out with vice chancellors (reitores), deputy vice chancellors, programme coordinators and researchers of four community universities in the state of Rio Grande do Sul. The data were analysed in relation to theoretical framings of public/private and contemporary demands on higher education in the context of the knowledge economy. This made possible the identification of contextual specificities, and an understanding of their interactions with higher education trends at the global level, in a comparative perspective. 
The article starts with a contextualisation of contemporary higher education, so as to present the debate concerning the new demands that have emerged leading to the reconfiguration of higher education institutions (HEIs), and an outline of theoretical ideas relating to the public good in higher education. Following that, the community universities of the South of Brazil are introduced, assessing the ways in which they can be identified as community-based. An analysis is thereby developed with the purpose of assessing the alignment of the emerging demands for HEls and the characteristics of the Brazilian community universities. Finally, it is argued that these universities possess characteristics of a hybrid model, ones that configure them as a non-state public alternative, and as generative in responding to both the traditional and the emerging demands on universities.

\section{New realities and demands for higher education institutions}

Higher education has attracted unprecedented attention in the $21^{\text {st }}$ century. According to Castells (2005), the new world order associated with the rise of communication and information technologies that arose in the 1960s has led to the emergence of the so-called 'knowledge economy', in which knowledge has become a strategic factor, supplanting physical capital (García 2003), and becoming one of the most valuable possessions of individuals (Marcelo 2001). In this new global economic settlement, involving a movement from industrial economies to ones in which knowledge is the primary raw material, universities play a preeminent role (Castells 2005; García 2003; Marcelo 2001; Slaughter and Rhoades 2004; UNESCO 2005, 2009).

There has been a corresponding expansion of access to the tertiary level in the vast majority of countries (Osborne 2003; Ilie and Rose 2016; Marginson 2016). At the same time, universities have been increasingly called on by governments and industry to contribute to economic development, creating wealth through knowledge (Jongbloed 2015; Etzkowitz, et al. 2000). Paradoxically, the rising expectations placed on universities bring with them a crisis in the traditional model of $\mathrm{HEl}$, accompanied by a certain loss of identity on the part of these institutions (Collini 2012). In this new context, the university has been criticised for its elitism and its 'ivory tower' separation from society, and there have been calls for a university that is more strongly engaged, one capable of innovating and responding nimbly to the practical challenges of the outside world (Jongbloed 2015; McCowan 2016a; Santiago et. al. 2008; UNESCO 2009).

Given this backdrop, debates over institutional models have gained force (Barber et al. 2013; Etzkowitz, et al. 2000). On the one hand, the ability of traditional models of the university to respond adequately to the demands of the knowledge economy has been questioned, leading to pressures for greater involvement of markets in higher education. In light of the framing of higher education as a private good by institutions such as the World Bank (e.g. 1998), there has been a retreat of the state and encroaching commodification of higher education, both in relation to teaching and research. Bruner and Uribe (2007) outline the following ways in which market logic has been incorporated: the emergence of for-profit institutions, the creation of markets in higher education, introduction of fees for students, reduction in public funding and encouragement for institutions to seek private sources of funds. Furthermore, as highlighted by Amaral (2009), institutions have shifted their governance models from collegial structures 
- criticised for their lack of agility and susceptibility to corporatism - to professional management along a business model.

On the other hand, there have been doubts about whether the embracing of the market is consonant with the preservation of values such as collegiality, autonomy and research in the public interest, in turn leading to pressures for the continuing involvement of the state in the promotion of higher education as a public good (Nixon 2011; Santos 2004; Rhoades and Slaughter 2009; Singh 2011; UNESCO 2009). The public nature of higher education has also been defended from the perspective of its role in developing citizenship, and improvement of the social and economic conditions of society (Kezar, Chambers, and Burkhardt 2005; Brennan, King, and Lebeau 2004; Walker and McLean 2013).

While policies of higher education marketisation have been adopted throughout the world, the debate is, therefore, far from being consensual, involving contested issues relating to finance (Jongbloed 2007), commodification (McCowan 2004, 2016a; Geiger 2007), unbundling (McCowan 2017) and models of governance (Amaral, Jones, and Karseth 2002). What is certain is that HEls in interaction with their environment are currently passing through a process of transformation, and for that reason it is impossible to classify them in a univocal and decisive way. In this way, Slaughter and Rhoades (2004) have argued that, while there is a shift from a 'public good knowledge/learning regime' towards an 'academic capitalist knowledge/learning regime', in which knowledge is taken as a private good, this does not signify a simple substitution of the former with the latter. Instead, not only do the two regimes coexist, but they cross and overlap.

The question of what constitutes public or private higher education is ill-defined and has become remarkably complex in the context of contemporary economic and political transformations. The conventional associations between 'public' and the 'state', and 'private' and the 'market', as well as classifications based on legal ownership, are insufficient, and do not have the necessary reach to encompass this complex reality (Marginson 2006). An initial distinction can be made between ownership/management and funding. Many state universities in the contemporary age charge fees - in some cases the full cost of the courses provided - and in many parts of the world, the state regulates higher education on the basis of market principles, creating quasi-markets. Equally, private universities in many cases receive state subsidies; some charge low fees to students or no fees at all (Marginson 2006, 49). Further considerations are needed on the nature of the goods produced, with public institutions producing a range of private goods, and conversely, private institutions (particularly non-profit ones) capable of producing public goods.

Marginson, therefore, argues that in the real world the division between public and private is less solid than it initially appears, and warns that a naturalising and universalising perspective on the public-private relationship currently adopted in higher education:

blinds us to the complex mixing of public and private qualities that takes place in actual institutions, and higher education systems. Yet these complexities are readily identified empirically. We occlude them theoretically only by violating our processes of observation. (Marginson 2007, 310) 
It is important also to highlight the significant differences between for-profit and non-profit sectors in higher education. While some non-profit institutions (and indeed some public ones) operate on a highly commercialised basis, the traditional philanthropic and religious institutions operating on a non-profit basis have a significantly distinct ethos and modus operandi from the new profit-making sector that is expanding rapidly in countries such as the USA and Brazil. In many cases, for-profit institutions are controlled by large conglomerates, thereby conforming not only to the day-to-day logic of profit making, but also to the demands of shareholders.

In highlighting the complexities of public and private, we are not arguing that these categories are no longer consequential; on the contrary, they are highly significant for questions of social justice, and the quality and impact of teaching, learning and research. Nevertheless, it is important to acknowledge the increasingly subtle and complex relationship between public and private in contemporary higher education, based on two presuppositions: 1) public and private are not fixed or natural characteristics, but can vary across time and space; 2 ) it is difficult to identify purely public or private institutions, given their inherent complexity. This entails recognising that public and private exist in a variable mixture within institutions, whose composition is not predefined. The balance between public and private is determined not only by ownership, or by natural and inherent characteristics, but by social and political choices and 'the day-to-day practices of personnel' (Marginson 2007, 315). These choices are made at the broader level of regulation of higher education systems, but also in the purposes of the institutional level and the objectives and practices of university managers and other actors.

It is in this context that the notion of 'non-state public' can emerge and gain legitimacy. According to this conception, institutions not classified as state entities may still possess public ends. The non-state public, therefore, is distinct from the commercial - characterised by private ends - and also from state-controlled entities. For Santos $(2005,157)$, in a society in which the welfare state is limited, there is 'necessity for a welfare society'. It is a question, therefore, of creating 'a third sector, situated between state and market, which organises the production and reproduction (the social security) in a socially useful manner', one that is carried out by non-governmental organisations and social movements.

In the sense of Santos's $(2005,1998)$ proposition, the non-state public, also denominated the third sector, reveals a maturing of the relationship between state and civil society. It does not necessarily represent, as some analyses assert, a mechanism of substitution of the functions of the state in the context of a neoliberal offensive. It does indeed speak to a redefinition of the limits of public and private, which become less solid, broader and less clearly delineated. Legal ownership, in this context, shows itself as an inadequate interpretive criterion, without the reach necessary for the apprehension of the public-private relationship, it being more appropriate to broaden the conceptual base so as to consider conceptions of public-private of a political origin, as for example the idea of public sphere or public good.

In light of the above discussions, the question arises of which models are most appropriate to fill this non-state public space, and to balance, on the one hand, the preservation of academic values, and on the other the demands of community and industry. The idea of a hybrid university can be useful in this discussion. Mouwen (2000) asserts that the hybrid university is 
the university of the 21st century: that is to say, in the context of the knowledge economy, the university comes to characterise itself by a tense combination between demands related to the realisation of its traditional activities, and the new requirements emerging from its relationship with the market, which gives it a hybrid appearance (Mouwen 2000; Jongbloed 2015). The community universities in the South of Brazil, with their hybrid nature, appear well-placed to fulfil that role, situated as they are at the centre of the dichotomy.

In spite of the forms of community engagement practiced by most universities, community universities of the type analysed in this article are rare around the world. It is important to distinguish them from 'community colleges' in the USA, which, while serving local communities in terms of student intake, may not have the other characteristics outlined below, including their founding through community mobilisation and ongoing local democratic management. Furthermore, Brazilian community universities offer full degrees, rather than the two-year associate's degrees commonly offered by US community colleges. A number of characteristics of the community universities are shared by indigenous institutions in different countries, or others serving specific ethnic, linguistic or religious populations - and in many cases they have been created by the communities themselves. Examples of these include the Quechua, Aymara and Guaraní universities in Bolivia, the network of intercultural universities in Mexico, as well as the University of the Autonomous Regions of the Nicaraguan Caribbean Coast (Oyarzún et al. 2017; Dietz 2009; Mato 2008). However, these latter are distinct in providing a differentiated form of higher education, (culturally and linguistically) specific to that particular ethnic group, and are often available exclusively to members of that group. Lastly, there has in recent years been an emergence of grassroots cooperative universities - often associated with radical political movements: while these have some of the elements of the community universities, they are rarely accredited institutions with the full array of institutional functions, and so require a separate analysis (McCowan 2016b).

\section{The community universities in the South of Brazil}

The Brazilian higher education system is composed, in terms of ownership, of public state institutions and private institutions. The public ones - established and controlled by either by the federal government or one of the state (or in some cases municipal) governments - are almost entirely funded from public finances and are free of charge for students. For the most part, they are prestigious institutions, with highly competitive entrance exams, and thereby remain the preserve of the elites (McCowan 2016c). The private institutions, on the other hand, can be divided into for-profit and non-profit, both supported primarily by the charging of fees to students, although also receiving some governmental resources, especially the nonprofits. The latter are older and more traditional, and within this group can be found the Catholic universities as well as the community institutions that are the focus of this article. The for-profit HEls emerged more recently, through legislation that dates from the end of the 1990s, and are clearly located within a market dynamic, characterised by a growing process of acquisitions and mergers by large educational groups, some listed on the stock exchange (Sampaio 2014; Carvalho 2013). However, there are also some higher education institutions in Brazil formally classified as non-profit, but which are highly commercialised, with management practices similar to those of the for-profit sector (Schmidt 2014). 
Brazil has undergone a rapid expansion of enrolment rates at the tertiary level, with the net enrolment ratio (NER) rising from 6\% in 1997 to 18.1\% in 2015 (Brazil/INEP 2016). Furthermore, the country has committed itself to increase this rate to 33\% by 2024 (Brazil 2014). In relation to the growth observed until now, the private sector has had the major role, in particular the for-profit institutions, which have grown exponentially since the late 1990s (Koppe 2014). According to Sampaio $(2014,48)$, ' 15 educational groups control $36 \%$ of the higher education market and receive $27 \%$ of the revenue; 10 years ago, the 10 largest groups controlled just $14 \%$ of the market'.

Of the $2500 \mathrm{HEls}$ in Brazil, just under 250 are concentrated in Rio Grande do Sul and Santa Catarina, the states in which the community institutions analysed in this article are located. In these states, the NER is somewhat higher than the national average, being in Rio Grande do Sul $21.3 \%$, and in Santa Catarina, $23.2 \%$. There are 24 community HEls across the two states ${ }^{1}$. These are all secular institutions, originating from the decades of the 1940s to 1970s from the sphere of civil society, the fruit of mobilisation of regional communities, with the help of local leaders and organisations, with the aim of 'interiorising' higher education (making it available in smaller cities outside of state capitals), in a context of absence of state involvement (Neves 1995; Schmidt 2010; Vanucchi 2013).

The community institution model is one which carries with it the cultural inheritance of the community schools created in the 19th century by European immigrants who settled in the South of the country - primarily Germans, but later also Polish and Italians. These schools were built and maintained by the settlers in order to educate their children (Bittar 2011; Vanucchi 2013). Thus, the use of the term 'community' in the denomination of these HEIs is linked to its origin in the commitment to the development of the regional community. That commitment can be observed, on the one hand, in the profile of the students, for the most part originating from the region, and on the other hand, through practices of research and community engagement that aim to promote socio-economic development in the surrounding municipalities (Longhi 1998). In the mottos of some of the community universities, such as 'Feet in the region, eyes on the world"' (University of Caxias do Sul) or alternatively, 'Transforming people to transform the world' and 'The university of our community' (University of Passo Fundo) it is possible to recognise the community identity that structures them. This commitment to community has maintained itself through the decades, despite acquiring new nuances faced with the transformations that the field of higher education presents in the so-called knowledge economy (Fioreze 2017).

In relation to governance, the community universities are constituted as non-profit institutions: they do not have private owners and belong to a foundation or association. In accordance with national legislation (Brazil 2013), they cannot generate profit, and any financial surplus arising must be reinvested in the university. In the case of the dissolution of a community university, its estate must be passed over to a public institution or similar entity. Management is based on transparency and collegiality, with the participation of regional

\footnotetext{
${ }^{1}$ Some of these institutions are classified as 'universities' and others as 'university centres', according to Brazilian legislation. Universities have greater autonomy than university centres for opening new courses, but are obliged to meet more stringent requirements, for example, in terms of research and community engagement. For the purposes of this article, both types are called community universities.

${ }^{2}$ All translations of documents and interviews from the original Portuguese are the authors'.
} 
community members in the deliberative bodies, as well as representation of the different academic segments (lecturers, non-academic staff and students). Their vice chancellors are representatives of the lecturers, chosen through democratic procedures (Brazil 2013; Schmidt 2008; Vanucchi 2013).

In terms of funding, they sustain themselves using a combination of private and public resources: the former from fees paid by students, and the latter from tax exemptions, and from competitive funding provided for scholarships for students, and grants for those who cannot afford the fees, as well as funding for activities of research and community engagement. Estimates, based on institutional documentation (Fioreze 2017), indicate that approximately $80 \%$ of their funds are private and $20 \%$ are public.

The community universities seek to be recognised as public, despite not being state institutions. In the Brazilian context, however, to consider institutions of private ownership as public is not something widely accepted. The country is characterised by a historical culture in which, in part due to the adopted Napoleonic tradition, the public is strongly associated with the state. As explained by Carvalho (2001), instead of constructing citizenship from society, the historical process in Brazil was top-down, with the state being the central agent of social and political dynamics, and responsible for development and modernisation. As a result, the country was characterised by a weak civic tradition, and because of this, a context emerged in which civil society initiatives, like those situated in the non-state public space, have been viewed with a certain distrust, impeding their recognition as being legitimately public. This reality is distinct from, for example, the Anglo-Saxon countries, in which there was a historical construction of citizenship from the bottom-up, as well as a tradition in which the public outside of the state finds a space to function with the due social legitimacy. A similar trend to that of Brazil can be seen in Argentina, as explored by Oria (2013) in relation to the submerging of the non-state public tradition in the country, in favour of a highly state-centric focus from the early 20th century.

The community model of university, in claiming its public non-state character, aims to challenge this historical background by broadening the conception of the public beyond the limits of the state. Understanding the community universities from this prism signifies, on the one hand, conceiving them as public on account of their regional and community commitment, and of their governance, which distinguishes them from the entrepreneurial private institutions. On the other hand, it means recognising that despite being public, they do not belong to the state, and unlike the public state universities in Brazil, charge fees.

\section{The community model in the face of demands on the higher education sector}

Keeping in mind the particular characteristics of community universities, there will now be an assessment of the extent to which these institutions can constitute an alternative to address the demands made on higher education in Brazil in the context of the knowledge economy. As discussed above, HEls are required in contemporary times to have closer links with and to be more responsive to their communities, seen most clearly through demands for innovative solutions for the business sector, but also for solutions in terms of social innovation. In Brazil, initiatives in relation to innovation and technology transfer are not in general as strong as in 
Europe and the USA, in which policies and investments in this direction are influential, as shown by Neves and Neves (2011).

Given the above, the following questions are raised: considering the context of Brazilian higher education, how is it possible to guarantee at the same time responding to the demands of industry and preservation of the central values such as autonomy, collegiality and the public good? To what extent do the community universities present characteristics that could situate them as an alternative in the face of these challenges?

Commitment to the development of their communities, in addition to being enshrined in the law that regulates the community institutions (Brazil 2013), also expresses itself in the discourses analysed in this study, as a founding principle of institutional model. This understanding represents a consensus observed amongst those interviewed in addition to the institutional documents. As stated by the interviewee below:

We are fixated, I would say, on the regional community, and the extent of this involvement could only be perceived in an extreme situation, if the university stopped existing. Then the loss to the region and the loss to the city would be clear. It's that the ties are very big, very strong. (Former deputy vice chancellor for planning of a community university in Rio Grande do Sul)

Another respondent, a deputy vice chancellor for research, stated: 'The university produces a sense of belonging, one which reinforces its identity as an institution that participates in the daily life of each region where it locates a campus'.

The institutional documents, in turn, express this same idea of belonging, as can be seen for example in the institutional mission established by Unijuí (a community university in Rio Grande do Sul), namely: 'to form professionals, to construct scientific and technological knowledge and to promote cultural actions constituting the integration and development of the north-west region of the state'. Likewise, the vision proposed by Unisc is:

to be a university that is democratic and of the community, recognised by relevant contributions to development, capable of responding in a creative and dynamic way to the transformations of the social context.

The materialisation of this commitment to the development of the community is made in different ways. The analysis carried out of institutional discourse indicates that the service (extensão) activities constitute the principal and oldest mediation of the relationship between university and community development, through social projects which take place especially with groups in a situation of socio-economic disadvantage. As expressed by one of the interviewees, a former deputy vice chancellor for planning, what is clear in the community model is 'the idea that service is a differentiating characteristic'. These activities, however, have a cost, one that is covered predominantly from the fee payments of students. In a context of marketised competition, increases in fee levels (resulting from the necessity of costing activities not directly related to teaching) becomes a problem for the survival of the community institutions. This is because they are competing with the commercial for-profit institutions which generally do not carry out any significant activities of research or service, 
allowing them to keep their fee levels low. The institutional representatives interviewed, despite recognising the necessity of maintaining service projects as part of the nature of the institutional model, vocalised the necessity of 'finding other means of financing this activity, because in some form it needs to be costed.... We don't think it's fair that the undergraduate student should have to bear these costs' (Deputy vice chancellor of a community university in Rio Grande do Sul).

Despite service being the most traditional form of link with the community, a growing movement in community universities can be observed more recently towards establishment of scientific and technological parks. This involves the creation of spaces that prioritise partnership with industry and represent a new form of forging closer links with the community and their demands, through the means of applied research, oriented towards innovation and technology transfer. In the words of one interviewee: 'I believe that the partnerships that are being established can generate technological products of quality, ones which can impact positively on the daily life of society' (Programme coordinator of a community university in Rio Grande do Sul).

While this kind of action is consonant with tendencies observed at the global level, a significant proportion of the interviewees - especially those who occupy the highest management levels - understand this new form of relationship with society as a differential in the community compared with the commercial institutions. The latter offer predominantly teaching, and are not involved with the types of activities are characteristic of scientific parks: as stated by one vice chancellor 'I understand that all of this puts us in a different situation from the merely commercial institutions, they don't offer this'.

On the other hand, the search for the establishment of partnerships with industry to develop technologies also appears as a possibility of developing self-sustaining research activities. This strategy is repeatedly evidenced in the institutional documents as a way of mitigating the challenges of funding in the context of the aforementioned market competition. In the words of one of the interviewees:

we are also creating research towards solving the more concrete problems of businesses, so we can also achieve sustainability.... That's to say, we are competing for students, but the numbers are going down, and our financial basis is being corroded. So undergraduate teaching is no longer able to sustain research. (Vice chancellor of a community university in Rio Grande do Sul)

In relation to these links with communities, it is important to highlight that the mission and objectives of the community universities are constructed collectively within the deliberative bodies, in which, beyond the participation of different internal actors, there is also participation of representatives from the outside world. This is specified in institutional documents, in particular their Internal Statutes and Regulations. It is important to emphasise also that collegiality is a legal requirement, since according to the law that regulates community HEls, in order to be recognised as such they must guarantee 'the participation of representatives of academic staff, students and professional staff in collegial, academic, deliberative organs of the institution' (Brazil 2013). 
Analysing the democratic and collegial profile of the community institutions, with participation of the community in decision-making, it can be observed that this aspect can constitute a guarantee of the preservation of the public dimension of the university in the sense of providing a brake on the processes of commodification. In this way the institutional model is subject to public control, both by the academic public and by civil society outside the institution. The deliberative bodies constitute, then, a form of public sphere (as discussed in Marginson 2006), which guarantees that the distinctive interest groups can debate their concerns and construct consensuses. In this sense, they are bodies that can balance the demands of responsiveness to industry, with attention to social necessities linked to reduction of inequalities. The same bodies can also preserve values such as autonomy, academic quality and open dissemination of knowledge, vital characteristics of the university oriented towards the public good, while at the same time guaranteeing the necessary distancing from the notion of the ivory tower.

This collegial characteristic with broad participation of civil society distinguishes the model from the entrepreneurial institutions whose governance, according to Sampaio $(2014,50)$, is carried out through professional staff disjointed from the academic body, following a centralised business model. In this sense, it is interesting to highlight a view put forward with a certain regularity in the data collected, that in the context of competition and crisis currently experienced, the collegial and democratic model of management should not be substituted with a vertical model inspired by business - as might at first appear on account of contemporary demands for greater agility in institutional processes. On the contrary, respondents argue that the participatory structure should be strengthened as a differentiating characteristic of the community universities. This strengthening is, in this way, understood as a condition for survival and broadening of the competitive capacity of the HEls in the current landscape. Illustrative in this regard are the statements of institutional representatives such as 'our times still require democratic processes' (Deputy vice chancellor for community engagement), or 'a community institution has to work with the dimension of participation, it needs to be like that, to characterize all the processes' (Deputy vice chancellor for research), or 'this story that we are slow, because it takes a long time to take decisions, it's very relative... And the results at the end of the day, in our institutions, show in our favour' (Former deputy vice chancellor for planning).

Another aspect that can be examined is academic quality. On analysing data from the quality evaluation system used in the Brazilian higher education system (SINAES), it can be observed that the community universities and the federal institutions present similar results. Information available from E-mec (Brazil 2016) shows that, in the state of Rio Grande do Sul, of the seven community institutions evaluated, three have a rating of 3 , four have a rating of 4 , and one the maximum of 5 . Amongst the seven federal universities, three obtained 3 and four obtained 4. In the state of Santa Catarina, all of the federal and community institutions obtained a rating of 4 . These results show us that, while the federal institutions are the most prestigious, it is not possible to observe a great difference in terms of academic quality compared to the community ones.

Finally, it is also pertinent to analyse the community institutions from the perspective of funding, a central theme in debates around Brazilian higher education (Corbucci 2004; Nunes 
2007). In this respect, there are ongoing criticisms of federal and state institutions, whose high cost to the state in comparison with investment in basic education has laid bare the budgetary limits of conducting the expansion of access through these institutions. According to a study by Vonbun and Mendonça (2012), Brazil's expenditure per student in public higher education constituted a multiple of 1.08 of per capita GDP, while spending on primary education was just 0.16. The same study shows that (using figures for 2005) spending in the private sector was much lower than in the public sector, at only 0.4 of GDP per capita. However, caution is needed in interpreting these figures, given the extra costs incurred in public institutions relating to research, community engagement, pensions, hospitals and a range of other services that - while common in non-profit private HEls, such as community and religious universities - are rare in for-profit private institutions. According to research developed by Bittencourt (2016), it is estimated that the annual cost per student in community universities in Rio Grande do Sul is $\mathrm{R} \$ 11,600$, whereas the cost per student in federal institutions is $\mathrm{R} \$$ 42,000 (considering salary costs of academic and non-academic staff, tax payments and faceto-face student costs). Considering also investments (in research and other expenditure), the cost is $R \$ 15,200$ in community institutions and $R \$ 49,300$ in federal institutions.

The community institutions have a funding base that combines private and public resources, with a predominance of the former. They function on the basis of a self-sustaining financing model that could constitute a viable alternative, in which there is recognition of the need for public funds directed at scholarships and grants for students who cannot afford the fees. Furthermore, the possibility of government policies directed towards making available public resources for community HEls could constitute an effective response to the challenges of financing of activities not directly related with teaching (like research and service) in the context of market competition. In this regard, there has been a change recently with the Community University Law (Brazil 2013), that allowed community universities the possibility of receiving public funding, but there is still less public support than they need.

However, the analysis of the community model shows some challenges. One is linked to the form in which the landscape of higher education in Brazil has evolved, with a marked proliferation of commercialised higher education institutions. These institutions, with a lean structure focused on evening courses, a hierarchical and business-oriented logic of management, are able to offer undergraduate courses at a low cost (albeit of dubious quality). In the Brazilian context, the community and commodified models compete head-to-head in the market for students. This means that - in the interests of survival - the community model itself has shown some tendencies towards the process of commodification, thereby threatening some of its foundational characteristics. This tendency was shown in the institutional discourses in this study, through tensions that are part of the daily life of the institutions in contemporary times, leading to the adoption of measures such as: cuts in activities targeting low-income communities that were previously offered free of charge; limiting the access of local communities to university facilities, previously offered freely; closure or greater precariousness of courses without financial return, even if these are considered socially relevant and identified as part of the community mission (such as teacher education); and alteration in the structure of management of some HEls so as to adopt a less democratic and more business-inspired perspective. In this way, the phenomenon alluded to by Teixeira et al. $(2004,336)$ can be observed, when market forces compromise the resources 
of non-profit universities, and the latter are 'forced to act more like businesses in search of profit and will eliminate those previous subsidised activities that serve the public interest'.

Another challenge is related to the question of access. The community universities are located in a landscape in which private funding predominates through the charging of fees. Moreover, a considerable part of the courses offered charge fees that are prohibitive for the average Brazilian salary, particularly the more sought-after courses. Given this backdrop, it can be affirmed that equity of access is not guaranteed in the community model. The tuition fees can be more accessible for those students who have federal grants or loans, or ones offered by individual institutions (the research showed that some community universities offer discounts for lower-income students in particular courses, and a significant proportion provide student loans). Nevertheless, not all students can access these grants or loans, thereby ensuring the continuing exclusion of disadvantaged populations from higher education.

\section{Conclusions}

This article has explored the ways in which the public good role of universities manifests itself in relation to the local. In contrast to more restrictive views of university engagement focusing solely on the role of the institution as a technology hub, the community universities in southern Brazil are organically linked to their regions. This relationship involves not only engaging in transfer and exchange of knowledge with industry and agriculture, and training professionals for work in the local area, but also the participation of community members in institutional governance, and broader community enjoyment of university services and facilities.

This case can aid in the reconceptualisation of local involvement of universities functioning both 'for the public good' and 'as a public good', in Locatelli's (2017) terms. The former relates to the instrumental role of the university in producing 'goods' in the plural - public by virtue of being non-rivalrous and non-excludable - such as developing environmentally friendly technologies, or forming health professionals better equipped to work with minority ethnic groups; or, more elusively, to mould a unitary sense of the public good through spaces for deliberation. The 'as a public good' sense relates to the extent to which higher education itself is accessible to and responsive to the public - relating to the expansion of availability of university places, and democratic management.

While the community universities have made significant contributions in relation to both of these roles, there are constraints. As outlined above, research and public service are largely funded through surplus from fee revenue, and therefore suffer from limited resources. Possibilities in this regards may be greater now since the passing of the Community University Law, which allowed community universities the possibility of receiving public funding, before restricted to state institutions, although it mainly recognized them as an alternative to offer public services in case of the absence of the state. Funding also forms a major constraint to the 'as a public good' role - as discussed above - given the obligation of the institution to charge fees, and thereby to risk excluding lower-income students who do not have access to loans or grants. 
Nevertheless, as a hybrid institutional model that situates itself in the middle ground between traditional and entrepreneurial universities, community universities represent an innovative and highly promising model of higher education. One key area is that they represent an organic response to the demands of the community, having their decision-making based on deliberative processes which take place within the collegial bodies. (In relation to this point, it has not been possible for this article to analyse the complex question of what constitutes the community, and whether disproportionate influence is captured by certain segments). These bodies, on account of the plurality of the actors involved, are constituted in true public spheres in which it is possible to guarantee the preservation of the idea of higher education as a public good, combined with that of the institutional commitment to the socio-economic development of the community. It is, then, a model that is characterised by the capacity of plasticity and resilience: plasticity in the sense of possessing the necessary flexibility for absorbing the demands placed on them by the practical world, ones which vary in time and space; and resilience in the sense of preserving the central academic values while moulding themselves to new situations and demands, that is, to have the capacity to adapt themselves in the face of strong external pressures, without reneging on their public commitments.

The community universities, therefore, comprise an institutional format that can be taken as a potential alternative in the movement for expansion of higher education with a guarantee of quality, since its hybridity makes possible the accommodation of demands placed at the door of the contemporary university, without compromising academic values. Beyond the Brazilian context, the model can constitute a possible alternative for other countries and contexts, given that the new demands placed on higher education and the processes of expansion of the tertiary level - and the search for solutions in terms of institutional models capable of balancing public and private - have been spread through the world. Nevertheless, it must be acknowledged that the emergence of the institutions is strongly predicated on distinctive characteristics of the communities of the South of Brazil and may not be possible to replicate elsewhere. In other words, the current characteristics of these universities can to a large extent be attributed to the movement that gave birth to them, one which was related to the specificities of socio-economic-cultural development of the South of Brazil. Faced with this understanding, it makes more sense therefore to think in terms of similar institutional arrangements in other contexts, rather than identical ones. Such arrangements necessarily need to respect the territorial specificities, although they cannot do away with the organic link with civil society through involvement with local communities, given that this constitutes the central nucleus of the community model.

Furthermore, it is important to point out that the community universities represent a form of social experience that expresses the protagonism of civil society in the construction of genuinely public spaces, beyond the state. The presence of private providers in the fulfilling of public functions, as is the case of the community universities, should not be understood as a disguised privatisation, as can be seen in some analyses that indiscriminately judge any nonstate initiative as neoliberal and, therefore, as privatisation of public responsibility. Analyses of this sort, based on a preconceived Manichaeism, limit our gaze on the experience that unravels itself in the day-to-day social life. They are, in this sense, understandings that impede the potential of publicness which can reside in an experience outside the state to be known and explored. Ultimately, they hinder civil society from flourishing and overcoming the traces of state paternalism that, in the case of Brazil specifically, still pertain. 
Analysing the interaction between university and society from the perspective of the former's contribution to the public good - or possibly, to the construction of the public good - shows that an organic link between institutions and communities is crucial for local development, as well as to advance social justice through social responsibility. The notion of public sphere is crucial here. As the public good refers to the good of a collectivity, the paths to be travelled by a university in the direction of the public good must be discussed collectively, with the participation of diverse social sectors.

However, it is important to highlight that the economics of the public and private dimensions of the community model are also related to the trajectory of education policies at the national and global levels. So, it is clear that the policies that drive universities towards processes of commercialisation, as well as those that encourage status competition (Marginson 2007) tendencies that can be observed nationally and globally - distance then from a perspective of contributing to the public good in and with their local communities. Status competition can encourage elitism in institutions, replacing commitment to social responsibility with concern for performance in national and international rankings. The quest for economic survival in a context of exacerbation of commercial private expansion (a growing feature in Brazil), pressures community universities to act as higher education businesses and can lead to cuts in social activities that do not lead to direct financial return, culminating in a disequilibrium caused by, on the one hand, a distancing of the university from disadvantaged segments of society, and on the other, from an excessive approximation to commercial sectors, processes that end up weakening the notion of the public.

\section{Acknowledgments}

This work was supported by CAPES (Coordenação de Aperfeiçoamento de Pessoal de Nível Superior/Brazil), under Grant 8004/14-5.

\section{References}

Amaral, A. 2009. Recent trends in European Higher Education. In Reforms and consequences in higher education systems: an international symposium. Center for National University Finance and Management, Tokyo.

Amaral, A., G. A. Jones, and B. Karseth. 2002. "Governing higher education: Comparing national perspectives." In Governing higher education: National perspectives on institutional governance, edited by A. Amaral, G. Jones, and B. Karseth, 279-298. Springer Netherlands.

Barber, M., K. Donnelly, S. Rizvi, and L. Summers. 2013. An avalanche is coming: Higher education and the revolution ahead. Institute for Public Policy Research.

Bittar, M. 2011. "Unijuí: expressão do segmento comunitário." In A Universidade no Brasil: concepções e modelos, edited by M. Morosini, 217-230. Brasília: INEP. 
Bittencourt, S. L. J. 2016. As instituições comunitárias de ensino superior do Rio Grande do Sul: análise de sua importância para o desenvolvimento socioeconômico regional. PhD diss., Universidade Federal do Rio Grande do Sul.

Blank, M. J., A. Melaville, and B. P. Shah. 2003. Making the difference: research and practice in community schools. Coalition for Community Schools, Institute for Educational Leadership.

Brazil. 2013. Lei no 12.881, de 12 de novembro de 2013. http://www.planalto. gov.br/ccivil_03/_Ato2011-2014/2013/Lei/L12881.htm. Accessed 15 Jul 2016.

Brazil. 2014. Lei no 13.005, de 25 de junho de 2014. http://www.planalto. gov.br/ccivil_03/_ato2011-2014/2014/lei//13005.htm. Accessed 15 Jul 2016.

Brazil. 2016. E-Mec. http://emec.mec.gov.br. Accessed 10 Nov 2016.

Brazil/Inep. 2016. Censos da Educação Superior. http://portal.inep.gov.br/web/censo-daeducacao-superior. Accessed 10 Nov 2016.

Brennan, J., R. King, and Y. Lebeau. 2004. "The Role of Universities in the Transformation of Societies". Centre for Higher Education Research and Information. http://www.open.ac.uk/cheri/documents/ transf- final- report.pdf

Brunner, J. J., and D. Uribe. 2007. Mercados universitários: el nuevo escenario de la educación superior. Santiago: Ediciones Universidad Diego Portales.

Carvalho, C. 2013. "A mercantilização da educação superior brasileira e as estratégias de mercado das instituições lucrativas". Revista Brasileira de educação, 18(54): 761-776. doi: 10.1590/S1413-24782013000300013.

Carvalho, J. M. 2001. Cidadania no Brasil: o longo caminho. Rio de Janeiro: Civilização Brasileira.

Castells, M. 2005. "A Sociedade em Rede: do Conhecimento à Política." In A sociedade em rede: do conhecimento à ação política, edited by M. Castells and G. Cardoso, 17-31. Portugal: Imprensa Nacional-Casa da Moeda.

Collini, S. 2012. What are universities for?. London: Penguin.

Corbucci, P. R. 2004. "Financiamento e democratização do acesso à educação superior no Brasil: da deserção do Estado ao projeto de reforma". Educação e Sociedade, 25 (88): 677-701. doi: 10.1590/S0101-73302004000300003.

Dietz, G. 2009. Intercultural Universities in Mexico: empowering indigenous peoples or mainstreaming multiculturalism?. Intercultural Education, 20 (1), 1-4.

Etzkowitz, H., A. Webster, C. Gebhardt, and B. Terra. 2000. "The future of the university and the university of the future: evolution of ivory tower to entrepreneurial paradigm". Research policy, 29(2): 313-330. doi: 10.1016/S0048-7333(99)00069-4.

Fioreze, C. 2017. O modelo comunitário de universidade e o tensionamento público-privado: entre o capitalismo acadêmico e o compromisso social. PhD diss., Universidade Federal do Rio Grande do Sul.

García, G. V. 2003. La función social de la educación superior en México. México: UNAM, Universidad Veracruzana. 
Geiger, R. L. 2007. "The publicness of private higher education: examples from the United States." In Public-private dynamics in higher education: expectations, developments and outcomes, edited by J. Enders and B. Jongbloed, 137-154. Transcript Verlag.

Gershberg, A. I., and B. Meade. 2005. "Parental contributions, school-level finances and decentralization: An analysis of Nicaraguan autonomous school budgets". Comparative Education, 41 (3): 291-308. doi: 10.1080/03050060500211658.

Gershberg, A. I., B. Meade, and S. Anderson. 2009. "Providing better education services to the poor: Accountability and context in the case of Guatemalan decentralization". International Journal of Educational Development, 29 (3): 187-200. doi: 10.1016/j.ijedudev.2008.08.002.

Ilie, S., and P. Rose. 2016. "Is equal access to higher education in South Asia and sub-Saharan Africa achievable by 2030?" Higher Education, 72 (4): 435-455. doi:10.1007/s10734-0160039-3.

Jongbloed, B. 2007. "Creating public-private dynamics in higher education funding: a discussion of three options." In Public-private dynamics in higher education: expectations, developments and outcomes, edited by J. Enders and B. Jongbloed, 111136. Transcript Verlag.

Jongbloed, B. 2015. "Universities as Hybrid Organizations: trends, drivers and challenges for the European University". International Studies of Management \& Organization, 45(3): 207-225. doi: 10.1080/00208825.2015.1006027.

Kezar, A. J., A. C. Chambers, and J. C. Burkhardt, eds. 2005. Higher education for the public good: Emerging voices from a national movement. John Wiley \& Sons.

Koppe, L. R. 2014. Instituições de Ensino Superior Privadas: organizações de ensino com fins lucrativos no Rio Grande do Sul. PhD diss., Universidade Federal do Rio Grande do Sul.

Locatelli, R. 2017. Education as a public and common good: revisiting the role of the State in a context of growing marketization. Unpublished PhD diss. University of Bergamo, Italy.

Longhi, S. M. 1998. A face comunitária da universidade. PhD diss., Universidade Federal do Rio Grande do Sul.

Marcelo, C. 2001. "Aprender a enseñar para la Sociedad del Conocimiento". Revista Complutense de Educación, 12(2): 531-593. http://revistas.ucm.es/index.php/RCED/article/view/RCED0101220531A/16749.

Marginson, S, and G. Rhoades. 2002. "Beyond national states, markets, and systems of higher education: A glonacal agency heuristic." Higher education 43.3: 281-309. doi: https://doi.org/10.1023/A:1014699605875.

Marginson, S. 2006. "Putting 'public' back into the public university". Thesis Eleven, 84(1): 4459. doi: $10.1177 / 0725513606060519$.

Marginson, S. 2007. "The public/private divide in higher education: A global revision". Higher Education, 53(3): 307-333. doi: 10.1007/s10734-005-8230-y.

Marginson, S. 2016. "The worldwide trend to high participation higher education: Dynamics of social stratification in inclusive systems". Higher Education, 72 (4), 413-434. doi:10.1007/s10734-016-0016-x. 
Mato, D., ed. 2008. Diversidad Cultural e interculturalidad em educacion superior. Experiencias em America Latina y el Caribe (IESALC). Caracas: UNESCO-IESALC.

McCowan, T. 2004. "Tooley's seven virtues and the profit incentive in higher education". Journal for Critical Education Policy Studies, 2(2): 1-15.

McCowan, T. 2016a. "Universities and the post-2015 development agenda: an analytical framework". Higher Education, 72 (4): 505-525. doi: 10.1007/s10734-016-0035-7.

McCowan, T. 2016b. "Forging radical alternatives in higher education: the case of Brazil". Other Education, 5 (2): 196-220.

McCowan, T. 2016c. "Three dimensions of equity of access to higher education". Compare, 46 (4): 645-665. doi: 10.1080/03057925.2015.1043237.

McCowan, T. 2017. "Higher education, unbundling, and the end of the university as we know it". Oxford Review of Education, 43 (6): 733-748. doi: 10.1080/03054985.2017.1343712.

Miller-Grandvau, Y., and K. Yoder. 2002. A literature review of community schools in Africa. Support for Analysis and Research in African (SARA) Project, Academy for Educational Development.

Mouwen, K. 2000. "Strategy, structure and culture of the hybrid university: Towards the university of the 21st century". Tertiary Education \& Management, 6 (1): 47-56. doi:10.1023/A:1009645607018.

Mwiria, K.1990. Kenya's Harambee secondary school movement: The contradictions of public policy. Comparative Education Review, 34(3): 350-368.

Neves, C. E. B. 1995. Ensino superior privado no Rio Grande do Sul: a experiência das universidades comunitárias. São Paulo: Núcleo de Pesquisas sobre Ensino Superior da Universidade de São Paulo.

Neves, C. E. B., and F. M. Neves. 2011. "Pesquisa e inovação: novos desafios para a educação superior no Brasil e na Alemanha". Caderno CRH: Revista do Centro de Recursos Humanos. 24(63): 481-501. doi: 10.1590/S0103-49792011000300003.

Nixon, J. 2011. Higher education and the public good: Imagining the university. London and New York, NY: Continuum.

Nunes, E. 2007. "Desafio estratégico da política pública: o ensino superior brasileiro". Revista de administração pública, 41: 103-147. doi: 10.1590/\$0034-76122007000700008.

Oría, A. I. 2013. "Changing Meanings of Public Education in Argentina. A genealogy". PhD diss., Institute of Education, University of London.

Osborne, M. 2003. "Increasing or widening participation in higher education? - a European overview". European journal of education, 38(1): 5-24. doi: 10.1111/1467-3435.00125.

Oyarzún, J., Perales Franco, C. and McCowan, T. 2017. Indigenous higher education in Mexico and Brazil: between redistribution and recognition. Compare. 47 (6): 852-871. doi: 10.1080/03057925.2017.1354177.

Perkin, H. 2007. "History of universities". In International Handbook of Higher Education, edited by J. J. F. Forest and P. G. Altbach, 159-206. Dordrecht: Springer. 
Ransom, J. 2017a. Universities: harnessing their superpowers. KPMG. Available at: https://home.kpmg.com/uk/en/home/insights/2017/11/universities-harnessing-theirsuperpowers.html . Accessed: 03/12/17.

Ransom, J. 2017b. Mutual influence? Universities, cities and the future of internationalisation. British Council. https://www.britishcouncil.org/education/ihe/knowledgecentre/internationalisation/mutual-influence-universities-cities . Accessed: 03/12/17.

Rhoades, G., and S. Slaughter. 2009. "O capitalismo académico na nova economia: escolhas e desafios". In Capitalismo académico, edited by J. M. Paraskeva, 7-36. Mangualde, Portugal: Edições Pedago.

Sampaio, H. 2014. "Diversidade e diferenciação no ensino superior no Brasil: conceitos para discussão". Revista Brasileira de Ciências Sociais, 29(84): 43-55. doi:10.1590/S010269092014000100003.

Santiago, P., K. Tremblay, E. Basri, and E. Arnal. 2008. Tertiary education for the knowledge society. (Vol 2). Paris: OECD.

Santos, B. S. 1998. A reinvenção solidária e participativa do Estado. Seminário Internacional Sociedade e a Reforma do Estado. São Paulo: MARE.

Santos, B. S. 2004. A universidade no século XXI: para uma reforma democrática e emancipatória da universidade. São Paulo: Cortez.

Santos, B. S. 2005. A crítica da razão indolente: contra o desperdício da experiência. São Paulo: Cortez.

Schmidt, J. P. 2008. "O caráter público não-estatal da universidade comunitária: aspectos conceituais e jurídicos". Revista do Direito, 29: 44-66. doi: 10.17058/rdunisc.v0i29.658.

Schmidt, J. P. 2010. "O Comunitário em tempos de público não estatal". Avaliação, 15(1): 940. doi: $10.1590 /$ S1414-40772010000100002.

Schmidt, J. P. 2014. "Mercantilização da educação superior: o campo dos negócios e o papel das IES públicas e comunitárias". Textual/Sinpro, 2(20): 22-28. http://www.sinprors.org.br/textual/nov2014/pdfs/mercantilizacao.pdf.

Singh, M. (2011). The place of social justice in higher education and social change discourses. Compare: A Journal of Comparative and International Education, 41(4), 481494.

Slaughter, S., and G. Rhoades. 2004. Academic capitalism and the new economy: Markets, state, and higher education. Johns Hopkins University Press.

Stiglitz, J. E. 1999. "Knowledge as a global public good". In Global public goods, edited by Inge Kaul, Isabelle Grunberg, Marc A. Stern, 308-326. Published for United Nation Development Programme. New York/Oxford: Oxford University Press, 1999. p. 308-325.

Teixeira, P., B. Jongbloed, D. Dill, and A. Amaral, eds. 2004. Markets in Higher Education: rhetoric or reality? The Netherlands: Kluwer Academic Publishers.

UNESCO. 2005. UNESCO World Report Towards Knowledge Societies. Paris: UNESCO Publishing. 
UNESCO. 2009. World Conference on Higher Education: the new dynamics of higher education and research for societal change and development. Paris: UNESCO Publishing.

Vanucchi, A. 2013. A universidade comunitária: o que é, como se faz? São Paulo: Loyola.

Vogt, O. 2009. "Capital social e instituições comunitárias no Sul do Brasil." In Instituições comunitárias: instituições públicas não-estatais, edited by J. P. Schmidt, 51-68. Santa Cruz do Sul: Edunisc.

Vonbun, C., and J. L. O. Mendonça. 2012. Educação superior: uma comparação internacional e suas lições para o Brasil. Brasília: IPEA.

Walker, M., and M. McLean. 2013. Professional education, capabilities and the public good: The role of universities in promoting human development. Abingdon: Routledge.

Watson, D., R. M. Hollister, S. E. Stroud, and E. Babcock. 2011. The engaged university: International perspectives on civic engagement. Abingdon: Routledge.

Wissema, J. G. 2009. Towards the Third Generation University: Managing the University in Transition. Cheltenham: Edward Elgar.

World Bank. 1998. The Financing and Management of Higher Education: a status report on worldwide reforms. Washington: World Bank Human Development Group. 